\title{
Diana Wasilewska
}

\section{W POSZUKIWANIU NOWOCZESNEGO JEZYKA KRYTYCZNEGO. SZTUKA AWANGARDOWA W UJECCIU STEFANII ZAHORSKIEJ ${ }^{1}$}

\begin{abstract}
Abstrakt
Tekst jest próbą przyjrzenia się krytycznemu pisarstwu Stefanii Zahorskiej, przede wszystkim z uwzględnieniem wystąpień krytyczki dotyczących awangardy. Analizie poddane zostały ewoluujące poglądy autorki, jej koncepcja sztuki, uwzględniająca również estetyczne i metodologiczne inspiracje, a także kryteria, jakie stosowała do oceny dzieł czy kierunków artystycznych. Dokonując druzgocącej diagnozy stanu międzywojennego pisarstwa o sztuce, Zahorska wielokrotnie apelowała o odrzucenie impresjonistycznej schedy i stworzenie nowego modelu krytyki artystycznej, będącego w stanie zmierzyć się ze sztuką nowoczesną. Odpowiedzią na te potrzeby miała być również jej własna praktyka krytyczna. Dlatego przedmiotem artykułu jest również język krytyczny Zahorskiej - pojęcia wypracowane przez krytyczkę, retoryka wypowiedzi, dominujący w tekstach styl odbioru itp. Jest to zarazem sposób, by oddać specyfikę pisarstwa Zahorskiej i określić jej miejsce na mapie międzywojennej krytyki artystycznej w Polsce.
\end{abstract}

\section{Słowa kluczowe}

Stefania Zahorska, dwudziestolecie międzywojenne, krytyka artystyczna, awangarda, forma

\footnotetext{
${ }^{1}$ Niniejszy artykuł nie ma ambicji wyczerpującego opracowania dorobku krytycznego Stefanii Zahorskiej. Interesuje mnie tu przede wszystkim sposób, w jaki Zahorska realizowała model krytyki nowoczesnej, a także jak wyglądał jej stosunek do awangardy wielokrotnie przez nią omawianej zwłaszcza w latach dwudziestych XX wieku. W kolejnej dekadzie, kiedy wyczerpywał się etos awangardy, a na scenę sztuki w Polsce wkroczyli koloryści, znajdując się w epicentrum sporów o styl narodowy i społeczną odpowiedzialność artysty, Zahorska rzadko zabierała głos, poświęcając się głównie sprawom filmu i działalności reporterskiej. Dlatego też te kwestie pozostaną na marginesie moich rozważań. Więcej na temat ówczesnych sporów o pryncypia artystyczne zob. Diana Wasilewska, Mieczysław Treter - estetyk i krytyk sztuki oraz „szara eminencja" międzywojennego życia artystycznego w Polsce, Towarzystwo Autorów i Wydawców Prac Naukowych Universitas, Kraków 2019.
} 
Jednym z mierników krytycznej świadomości jest refleksja dotycząca samej krytyki - jej celów, metod, pojęć, kryteriów oceny itp. Motorem sprawczym rozwoju metakrytyki są na ogół zmiany, jakie zachodzą na polu sztuki czy literatury danego czasu, odsłaniają one bowiem z pełną jaskrawością niekompetencje i braki piszących, a przede wszystkim nieadekwatność narzędzi badawczych i dotychczasowych mierników wartości. Znamy to doskonale choćby $\mathrm{z}$ recepcji impresjonizmu, a przede wszystkim z doświadczeń plastyki awangardowej, która $\mathrm{w}$ największym stopniu przeciwstawiała się założeniom dotychczasowej estetyki. W Polsce rozwój refleksji metakrytycznej nastąpił w okresie międzywojennym wraz z torowaniem drogi sztuce programowo zrywającej $\mathrm{z}$ szeroko rozumianym impresjonizmem i symbolizującą secesją. Postulaty metakrytyczne $\mathrm{z}$ największym zaangażowaniem głosili wówczas twórcy młodzi, broniący się $\mathrm{w}$ ten sposób przed salwami niewybrednych inwektyw kierowanych $\mathrm{w}$ ich stronę zarówno przez niedouczonych sprawozdawców, jak i uznane autorytety w sprawach sztuki. Batalię o nową krytykę, wszczętą onegdaj przez Stanisława Witkiewicza, podjęli przede wszystkim formiści, a następnie kontynuowali, choć już z nieco mniejszym zacięciem, konstruktywiści i koloryści. Uderzając w mur niezrozumienia i nieakceptacji, z jakimi spotykała się ich sztuka, artyści sami przejmowali „krytyczne stery”, rozprawiając się z reliktami młodopolskiego pisarstwa wraz z jego perlistym stylem, emfazą i patetycznymi poematami o duszy. Metakrytyczna refleksja nie miała wówczas charakteru statycznego, nie rozwijała się w zaciszu gabinetów, lecz w ferworze polemik ideologicznych, debat programowych, ścierających się racji i zwalczających wzajemnie światopoglądów. Dominowały więc teksty paszkwilanckie, prześmiewcze, służące wykpieniu dotychczasowego modelu krytycznego. Walcząc z pojęciowym galimatiasem i nieudolnością piszących, twórcy bronili jednak przede wszystkim własnej artystycznej pozycji².

W sukurs plastykom przyszli też niektórzy z ówczesnych krytyków, tacy zwłaszcza, którzy - jak Stefania Zahorska - rekrutowali się spośród ówczesnych zwolenników tzw. nowej sztuki. Mimo czasem odmiennych wizji samej krytyki jednoczyli oni swe siły, by zwalczać przede wszystkim skrajnie dyletancką publicystykę kwitnącą w prasie codziennej, gdzie prym wiedli przygodni sprawozdawcy, a rzetelność leżała $w$ sferze trzeciorzędnych postulatów.

W swym sztandarowym tekście metakrytycznym z 1926 roku Zahorska bezceremonialnie wytykała piszącym anachroniczne poglądy, pojęciową gmatwaninę, dezorientację $\mathrm{w}$ sprawach najnowszej sztuki oraz ubogi aparat terminologiczny. Przyczyn nie szukała jednak w nieuctwie i złej woli krytyków, lecz w ich nieprzygotowaniu do nowych artystycznych realiów. Uważała

\footnotetext{
${ }^{2}$ Zob. Diana Wasilewska, Przełom czy kontynuacja. Polska krytyka artystyczna 1917-1930 wobec tradycji młodopolskiej, Towarzystwo Autorów i Wydawców Prac Naukowych Universitas, Kraków 2013.
} 
bowiem, iż tylko taka krytyka ma rację bytu, która zajmuje stanowisko zgodne $\mathrm{z}$ założeniem omawianego dzieła - z tej perspektywy wydaje swe pozytywne bądź negatywne sądy. „Tragikomiczny bałagan”, jaki widziała w powojennej krytyce - wciąż, mimo zmian na polu sztuki, tkwiącej w sferze wartości stworzonych przez estetykę poprzedniej generacji - oznaczał jej zdaniem posługiwanie się narzędziami wykształconymi do analizy i oceny sztuki impresjonistycznej:

Prosty, wzrokowy stosunek do rzeczywistości i niedający się skontrolować subiektywizm - oto podstawy, na których zbudowany został cały arsenał frazeologiczny: „pyszny”, „bajeczny”, „tryskający życiem - prawdą - nastrojem” (i Bóg wie czym). Pod tym frazesem kryło się albo - nic - albo, w najlepszym razie, owa impresyjna subiektywność, idąca na sznurku wschodów i zachodów słońca, ,jak żywych" portretów, itd. ${ }^{3}$

Z tym uzbrojeniem - jak nie bez racji zauważyła Zahorska - „krytyka znalazła się wobec modernizmu absolutnie bezsilna". Gdy zwrot w sztuce nie pociągnął za sobą niezbędnego zwrotu w krytyce, „wszystkie mierniki odmówiły posłuszeństwa". Recenzentom, wychowanym na światopoglądzie i zdobyczach poprzednich epok, pozostało błąkanie się po omacku i grzęźnięcie w beznadziejnej gmatwaninie słów, gdyż „dawny dobry, wypróbowany frazes” nie był już w stanie ,załatać ani jednej dziury”4.

\section{INTELEKTUALNA LAFIRYNDA}

Dokonując tej druzgocącej diagnozy stanu międzywojennego pisarstwa o sztuce, Zahorska apelowała o konieczność stworzenia nowych mierników i nowej metody - jednym słowem nowego modelu krytyki artystycznej, nieobciążonego schedą impresjonistyczną. W przeciwieństwie do artystów walczących z szeregami znawców o „rząd dusz” w sprawach sztuki, próbowała budować tożsamość krytyka w obrębie instytucji, wytyczając jednak wyraźną granicę między starą i młodą krytyką. Dowodząc, iż modernizm to nie tylko nowoczesne formy, ale przede wszystkim nowoczesny człowiek ${ }^{5}$, Zahorska zażądała również nowoczesnego krytyka. A właściwie nie tylko zażądała, ale też próbowała sama tym wymogom sprostać. Posiadała ku temu zresztą przyzwoite podstawy.

Debiutując tuż po wojnie, miała już za sobą wszechstronne wykształcenie: studiowała najpierw medycynę, którą po trzech latach porzuciła na rzecz historii sztuki, oraz filozofię, broniąc w 1919 roku dysertacji doktorskiej o początkach

\footnotetext{
${ }^{3}$ Stefania Zahorska, Krytyka wobec modernizmu, „Praesens” 1926, nr 1, s. 41.

${ }_{5}^{4}$ Ibidem (wszystkie cytaty w tym akapicie).

${ }^{5}$ Ibidem.
} 
odrodzenia w Polsce ${ }^{6}$. Studia, a następnie badania przeprowadzone częściowo za granicą dały jej możliwość zaznajomienia się z najnowszą literaturą przedmiotu, ale też szansę bezpośredniego obcowania $\mathrm{z}$ aktualną sztuką - nie tylko poprzez wystawy, lecz również kontakty ze środowiskiem radzieckiej i zachodniej awangardy ${ }^{7}$. Zahorska posiadała zatem wiedzę wspartą dogłębnym wykształceniem i oczytaniem, ale chciała również pokazać, że jest wolna od obciążeń właściwych krytykom starszej generacji. Ograniczanie się do obalania, demaskacji i dyskredytacji, dostrzegalne zwłaszcza u wojujących z ówczesną krytyką twórców formistycznych, uznała bowiem za dowód niemożności wyzwolenia się z obszaru negowanych wartości artystycznych. Sama nie poprzestawała więc na utyskiwaniach - tworząc pozytywny program krytyki, a przede wszystkim wdrażając go w swoją aktywność pisarsko-dydaktyczną, dowodziła jednocześnie, iż metakrytyka nie musi być tylko, jak chciał Wojciech Głowala, „rodzajem marzenia istniejącego obok praktyki” czy też rodzajem uświadomionej mitologii krytyki i sztuki ${ }^{8}$. Działaniom Zahorskiej towarzyszyło stałe poczucie misji bądź też, jak pisała Nasiłowska, poczucie odpowiedzialności intelektualisty za kształt nowoczesności ${ }^{9}$. Potrzebę sprostania temu zadaniu widać w aktywności krytyczki na wielu polach: nie tylko sztuk plastycznych, ale też filmu, teatru, literatury czy mody ${ }^{10}$. Sprawy szeroko rozumianej sztuki w słowniku krytycznym Zahorskiej nie funkcjonowały nigdy w izolacji od życia pozaartystycznego, na podobnej zasadzie traktowała ona również własną aktywność w polu kultury. Tworzyła więc krytykę, ale też pisała powieści, torowała

\footnotetext{
${ }^{6}$ Zob. Anna Nasiłowska, Stefania Zahorska i wiek XX [wstęp], w: Stefania Zahorska, Wybór pism. Reportaże, publicystyka, eseje, red. Anna Nasiłowska, Instytut Badań Literackich PAN, Warszawa 2010, s. 7.

${ }^{7}$ Efekt współpracy Zahorskiej z awangardowym środowiskiem radzieckim opisany został w jej Listach z Nowego Wschodu - reportażach publikowanych na łamach „Wiadomości Literackich”. Zob. także: Diana Wasilewska, Stefania Zahorska - pierwsza reporterka II Rzeczpospolitej, w: Kobiece dwudziestolecie 1918-1939, red. Radosław Sioma, Wydawnictwo Naukowe Uniwersytetu Mikołaja Kopernika, Torun 2018, s. 227-241.

${ }^{8}$ Wojciech Głowala, Młodopolska wyobraźnia metakrytyczna, Wydawnictwo Uniwersytetu Wrocławskiego, Wrocław 1985, s. 7.

${ }^{9}$ Anna Nasiłowska, Stefania Zahorska i wiek XX, s. 6.

${ }^{10}$ Wszechstronna działalność Zahorskiej doczekała się już kilku, zarówno ogólnych, jak i bardziej szczegółowych omówień. Sporo pisano o jej recenzjach filmowych, zob. Danuta Karcz, Stefanii Zahorskiej walka o treść, „Kwartalnik Filmowy” 1960, nr 1-2, s. 47-92; Anna Pilch, Symbolika form i kolorów. O krytyce artystycznej Stefanii Zahorskiej, Wydawnictwo Księgarnia Akademicka, Kraków 2004. Piotr Rudziński poświęcił krytyczce dysertację doktorską (nieopublikowaną, jej echem jest jedynie artykuł z tomu Sztuka dwudziestolecia międzywojennego, będący raczej streszczeniem kilku artykułów Zahorskiej), a Nasiłowska przypomniała jej rozproszone w czasopismach dokonania reporterskie (omówione m.in. przeze mnie w artykule poświęconym kobiecemu dwudziestoleciu). Istnieje również dedykowana Zahorskiej, wspomniana wyżej, monografia pióra Anny Pilch, która próbuje, choć niezbyt szczęśliwie, pochylić się zarówno nad krytyczną, jak i literacką spuścizną tej autorki. Stefania Zahorska wciąż zatem czeka na gruntowne i wnikliwe zbadanie swojej wszechstronnej aktywności przed wojną, a także w latach powojennych, podczas emigracji w Londynie.
} 
drogę społeczno-politycznemu reportażowi, a szwaczki i hafciarki uczyła wrażliwości estetycznej i umiejętności patrzenia na sztukę ${ }^{11}$. Jeśli jednak zatrzymamy się wyłącznie w obszarze uprawianej przez nią krytyki sztuk plastycznych i ograniczymy do drugiej połowy lat dwudziestych (to bowiem okres jej największej aktywności), zauważymy i w tym zakresie szerokie spektrum zainteresowań, a co za tym idzie, wielość uprawianych przez nią "gatunków" krytycznych. Zahorska nie stroniła od sprawozdań i recenzji z wystaw (od sztuki awangardowej po skrajnie konserwatywną), ale też pisała monografie poświęcone twórcom dawnym (Jan Matejko) czy współczesnym (Eugeniusz Zak), publikowała eseje z pogranicza estetyki i teorii artystycznej, dokonywała wnikliwego bilansu minionych nurtów, diagnozowała stan sztuki aktualnej, pisała syntetyczne dzieje polskiego malarstwa i wreszcie uczestniczyła w sporach o pryncypia epoki. Za każdym razem jej głos był wyrazisty, zdecydowany, nierzadko bezkompromisowy, zawsze wolny od kumoterstwa i koniunkturalizmu, ale przede wszystkim - był to głos słyszalny. Zahorska pisywała zarówno w periodykach związanych z awangardą, jak „Praesens” i „Wiek XX”, jak też w liberalnych „Wiadomościach Literackich” czy wreszcie w zachowawczych, profesorskich „Sztukach Pięknych”. Te ostatnie drukowały wypowiedzi krytyczki kilkukrotnie, choć - jak zastrzegali redaktorzy - poglądów i opinii autorki do końca nie podzielali ${ }^{12}$. Zahorska cieszyła się zatem niekwestionowanym uznaniem, i to nie tylko w środowisku krytyków, ale też literatów i artystów. Warto wspomnieć również, że jako „intelektualna lafirynda" z Wszechnicy Robotniczej zaznajamiała z psychologią Ernsta Kretschmera Czeladników w Szewcach Witkacego ${ }^{13}$. Tenże zresztą Witkacy, diagnozując poziom literackiej i artystycznej kultury w międzywojennej Polsce, uznał Zahorską „,najlepszym polskim krytykiem piszącym o malarstwie”"14, polecając jej analizy nie tylko laikom, ale też innym krytykom i sugerując ich przedrukowywanie „we wszystkich polskich pismach”15. W sukurs przyszedł mu Władysław Strzemiński, uznając prace Zahorskiej za kompendium wiedzy

\footnotetext{
${ }^{11}$ Ibidem, s. 13.

${ }^{12}$ Redakcja przy artykule Zahorskiej pt. O los polskiego impresjonizmu (,Sztuki Piękne” 1926/27, nr 7, s. 258) dodała taką adnotację: ,Zamieszczając powyższy, bardzo zajmujący artykuł cenionej naszej współpracowniczki, redakcja „Sztuk Pięknych” uważa za stosowne zaznaczyć, że nie jest on w całości wyrazem naszych poglądów".

${ }^{13} \mathrm{~W}$ dialogu Czeladnika I z Czeladnikiem II w Szewcach Witkacego podają takie oto słowa: „Ja, wicie Jędrek, znam Kretschmera z wykładów tej tam intelektualnej lafiryndy Zahorskiej w naszej Wolnej Wszechnicy Robotniczej”. Zob. Stanisław Ignacy Witkiewicz, Szewcy, w: idem, Dramaty, Państwowy Instytut Wydawniczy, Warszawa 1979, s. 377.

${ }^{14}$ Stanisław Ignacy Witkiewicz, O stosunku wyksztatcenia literackiego i filozoficznego artystycznego krytyka, w: idem, O znaczeniu filozofii dla krytyki i inne artykuty polemiczne, oprac. Jan Leszczyński, PWN, Warszawa 1976, s. 355 (pierwodruk: „Przegląd Wieczorny” 1927, nr 132).

${ }^{15}$ Stanisław Ignacy Witkiewicz, $O$ artystycznej i literackiej pseudokulturze, w: Bez kompromisu, red. Janusz Degler, Państwowy Instytut Wydawniczy, Warszawa 1976, s. 207 (pierwodruk: „Comoedia” 1926, nr 1).
} 
i narzędzie „uczenia się sposobu myślenia o rzeczach plastycznych”16. Marian Bohusz-Szyszko w swych wspomnieniach włączył Zahorską, obok Roberta Venturiego i André Malraux, do szeregu nielicznych krytyków wielkich ${ }^{17}$, Kazimierz Wierzyński poświęcił jej jeden ze swych wierszy ${ }^{18}$, Jan Laterański napisał o niej, że „była jasną i prostą drogą w dżungli drapieżnej i często chaotycznej sztuki współczesnej"19, a Józef Wittlin nie wahał się wyznać w jednym z listów: „Wśród tylu mężczyzn histeryków reprezentuje Pani trzeźwy, dojrzały i naprawdę europejski intelektualizm"20.

Wysoka pozycja społeczna i dogłębne przygotowanie Zahorskiej pokazują, iż kreślony przez nią portret krytyka nowoczesnego nie był jedynie portretem potencjalnym, funkcjonującym wyłącznie w sferze utopijnych czy wybiegających w przyszłość marzeń, lecz próbą usankcjonowania realizowanego przez nią pisarstwa. Wskazując na konieczność szukania nowych metod, nowego aparatu krytycznego będącego kontrpropozycją wobec frazeologii młodopolskiej i zgodnego ze specyfiką nowej sztuki, Zahorska chciała utorować drogę krytyce przyszłości $i^{21}$.

Jej misją stało się przede wszystkim zbudowanie nowego, pozbawionego balastu przeszłości, języka krytycznego. Realizacją tego celu stały się choćby wielokrotne próby wyjaśniania genezy i specyfiki poszczególnych kierunków artystycznych - od impresjonizmu po konstruktywistyczną abstrakcję. Był to efekt przekonania, że powszechne w kraju „dławienie” wszelkich eksperymentów pod hasłem zwalczania nonsensu i obrony „prawdziwej” sztuki wynika w dużym stopniu z braku odpowiednich predyspozycji - intelektualnych i emocjonalnych - ówczesnych krytyków, uniemożliwiających im zrozumienie założeń nowej sztuki, specyfiki jej poszukiwań: „Większość ludzi - pisała - cierpi na coś w rodzaju duchowej sklerozy. Giętkość i zdolność asymilacyjna ich aparatu chłonnego jest bardzo niewielka. W obawie przed tym, że jakieś ścianki mogą pęknąć, wolą okrawać życie i jego zjawiska. Zdaje mi się, że obok tego stanowiska, które wartościuje objawy życia w myśl istniejących już kategorii, musi chyba istnieć drugie: to, które stwarza nowe kategorie, ażeby nadążyć bogactwu życia" 22 .

\footnotetext{
${ }^{16}$ Władysław Strzemiński, Stefania Zahorska: „Impresjonizm a najnowsze malarstwo francuskie” [recenzja], ,Zwrotnica” 1926, nr 7, s. 205.

${ }^{17}$ Marian Bohusz-Szyszko, O sztuce, Wydawnictwo Oficyna Poetów i Malarzy, Londyn 1982 , s. 69.

${ }^{18}$ Chodzi o wiersz pt. Obraz. Zob. „Kultura” 1961, nr 7/8, s. 53.

${ }^{19}$ Jan Laterański, Do redaktora ,Wiadomości”, „Wiadomości” 1961, nr 38/39, s. 8.

${ }^{20}$ Informację podaję za: Paweł Kądziela, Nota edytorska, w: Stefania Zahorska, Szkice o literaturze i sztuce, Warszawa 1995, s. 105.

${ }^{21}$ Stefania Zahorska, Krytyka wobec modernizmu, s. 41.

${ }^{22}$ Eadem, Pro i contra, „Wiek XX” 1928, nr 1, s. 4.
} 
Nie mam wątpliwości, że Zahorska swoją wszechstronną aktywnością i ciągłym intelektualnym niedosytem próbowała nie tylko sprostać bogactwu życia, ale też owo życie - przynajmniej na polu kultury - kształtować.

\section{KONCEPCJA SZTUKI WEDŁUG STEFANII ZAHORSKIEJ}

Myślenie Zahorskiej o sztuce wolne było od prostych dychotomicznych opozycji właściwych wielu ówczesnym krytykom. Stała ona zdecydowanie po stronie nowatorstwa, co nie oznaczało jednak pisania ślepych i bałwochwalczych peanów na cześć awangardy; nie potępiała też w czambuł wszystkiego, co mieściło się poza jej obrębem. Reprezentowała model krytyki otwartej, pluralistycznej, domagającej się ciągłej weryfikacji i świadomej tymczasowości własnych ustaleń. Była to jednocześnie krytyka intencjonalna, mierząca wartość dzieła z uwzględnieniem stanowiska twórcy i założeń teoretycznych danego kierunku oraz respektująca szeroki wachlarz rozwiązań artystycznych i mnogość konwencji.

Rozmaite były też estetyczne i metodologiczne inspiracje Zahorskiej, czerpane z wielu, nierzadko wykluczających się, źródeł. Najbliżej, jak się zdaje, było jej do wykładni Wilhelma Worringera, któremu poświęciła nawet osobny tekst u zmierzchu lat pięćdziesiątych XX wieku ${ }^{23}$. Za autorem Abstrakcji $i$ wczucia polemizowała choćby $\mathrm{z}$ teorią Einfühlung Theodora Lippsa, stanowiąca podstawę ekspresyjnych teorii sztuki uznających siłę wyrazu za podstawowe kryterium aksjologiczne ${ }^{24}$. Zdaniem niemieckiego filozofa przedmiot pozbawiony ekspresji, nieposiadający mocy emocjonalnego oddziaływania i niemówiący nic o własnym wnętrzu pozostawia odbiorcę obojętnym, a tym samym wyklucza i uniemożliwia empatię, którą Lipps rozumiał jako czynność duchową, pozwalającą w dostrzeganych przedmiotach, ich kształtach, kolorach, odczuć silne walory emocjonalne i potraktować je jako własne. Zahorska nie odrzucała kryterium wyrazowego, choć raczej nie należało ono do nadrzędnych wyznaczników wartościowania w jej krytyce. U Lippsa doceniła przede wszystkim dostrzeganie w dziełach treści niezależnej od świata przedstawionego, szukanie jej w samych czynnikach plastycznych. Nie zgadzała się jednak z niemieckim psychologiem przekonującym, że jedyne źródło owych treści stanowi natura, choćby ujęta nienaśladowczo. Takie założenie krytyczka uważała za zbyt ubogie i ograniczające, a przy tym - biorąc pod uwagę całą historię sztuki, zwłaszcza ludów pozaeuropejskich - nieprawdziwe. I tu właśnie wsparciem i teoretyczną podbudową była dla niej zrywająca z ideą postępu teoria Aloisa Riegla oraz inspirowana nią książka Worringera pozwalająca traktować abstrakcję (choć

\footnotetext{
${ }^{23}$ Eadem, Niematerialistyczne teorie sztuki, „Wiadomości” 1958, nr 28 (641), s. 2.

${ }^{24}$ Eadem, Symbolika form, „Wiadomości” 1949, nr 42 (185), s. 2.
} 
wyłącznie geometryczną) jako wyraz woli artystycznej, której źródło leży w potrzebie ładu, jasności i prawidłowości, i która próbuje do nich dotrzeć poza złudą zmysłowego świata. Zahorska przejęła od Worringera owo ujmowanie abstrakcji w kategoriach psychologiczno-metafizycznych, a za Rieglem i Heinrichem Wölfflinem postrzegała sztukę jako wyraz stosunku artysty do świata i siebie samego czy też sublimację tego stosunku ujawniającą się poprzez wybraną formę - zarówno mimetyczną, jak i bezprzedmiotową 25 . W tym właśnie, w jej przekonaniu, leżała zasadnicza treść dzieła - treść niezależna od przedmiotu, bo wyrażająca się w charakterze obranych form, a więc potencjalnie istniejąca również w sztuce abstrakcyjnej. Więcej nawet. Zahorska przekonywała, że abstrakcja ze względu na brak przedmiotu jeszcze bardziej wyczula na znaczenie i sens form czy kolorów: „Jeśli sztuka może coś wyrazić mimo braku przedmiotu, oznacza, iż posiada swą treść"26.

Nobilitując abstrakcję, czy może raczej traktując ją jako równoprawny sposób wyrażania indywidualnego i zbiorowego stosunku do rzeczywistości, krytyczka ostrzegała jednocześnie przed pułapkami, jakie niesie za sobą ten sposób obrazowania. Dowodziła, iż sztuka „od pierwszych swoich zaczątków aż do najbardziej skomplikowanych objawów" jest próbą ustalenia własnego stosunku do „oszałamiającej zmienności zjawisk”, która tym się jednak różni od filozoficznych dziejów myśli ludzkiej, że tylko w niewielkim stopniu operuje rozumem - jej domeną jest raczej podświadomy wysiłek twórczy, wyobraźnia oraz intuicja ${ }^{27}$. Opierając się na teorii Benedetta Crocego, a przede wszystkim tezach Henry'ego Bergsona i poniekąd też psychoanalizy, Zahorska nieufnie podchodziła do ekwilibrystyki formalnej i suchego intelektualizmu. Ekspresja samej formy czy barwy, pisała, jest mglista, niepewna, trudna do przeniknięcia, dzięki czemu łatwo sprowadzić ją do czystej ornamentyki, a tym samym do zbanalizowanej i pozbawionej wszelkiego sensu ozdoby mieszczańskich domów ${ }^{28}$. Takie niebezpieczeństwa widziała już w malarstwie kubistycznym dojrzałej fazy, w którym doszło do całkowitego zatarcia pierwotnego przedmiotu. Kubizm, zgodnie z opisanymi wyżej wytycznymi, krytyczka traktowała jako konieczny zwrot artystyczny służący opanowaniu rozbitej w impresjonizmie formy i rozluźnionej kompozycji. Przekonywała jednak, że owo pchnięcie „,nożem w brzuch” tradycyjnej estetyki nie sprowadziło gruntownej przemiany. Sprawy formy kubizm rozwiązał tylko połowicznie, zostawiając na boku ,rozprawę z rzeczywistością", tj. zagadnienie stosunku do przedmiotu, i podążając w kierunku sztuki abstrakcyjnej sprowadzanej do czysto „dekoracyjnego układu

\footnotetext{
${ }^{25}$ Zob. Anna Pilch, Symbolika form i kolorów. O krytyce artystycznej Stefanii Zahorskiej, Wydawnictwo Księgarnia Akademicka, Kraków 2004.

${ }^{26}$ Stefania Zahorska, Treść czy abstrakcja, „Wiek XX” 1928, nr 13, s. 4.

${ }^{27}$ Eadem, Filozofia ekspresjonizmu. (Uwagi na tle malarstwa), „Przegląd Warszawski” 1924, nr 28, s. 49.

${ }^{28}$ Eadem, Malarstwo Picassa, „Wiadomości” 1950, nr 51/52 (247/248), s. 2.
} 
barwnych płaszczyzn"29. Płytki, przeintelektualizowany formalizm, abstrakcję „wydestylowaną" z jakiejkolwiek ekspresji i wyzutą z treści Zahorska uznała za grubą pomyłkę prowadzącą sztukę do wewnętrznej martwoty, czystej dekoracyjności. Doceniła dokonania sztuki kubistycznej i geometrycznej abstrakcji, przede wszystkim ze względu na przewrót formalny i nowy stosunek do obrazu, jednak uważała je za etap przejściowy, który ustąpić musi nowej koncepcji form. Wieszczyła więc nadejście nowego realizmu, rozumianego nie jako paseistyczny powrót do źródeł, lecz konieczne następstwo abstrakcji wyciągające $\mathrm{z}$ jej osiągnięć nowe, cenne wnioski, tworzące nowe koncepcje formalne $\mathrm{e}^{30}$.

Twórczość abstrakcyjną sprowadzoną do czystego formalizmu, tak samo jak przedmiotową dekoracyjność, Zahorska odrzuciła $\mathrm{z}$ jeszcze jednego powodu. Otóż tego rodzaju dzieła nie były w stanie sprostać znaczeniu, jakie krytyczka przydawała sztuce. Przekonywała bowiem - znów za Worringerem - że zagadnienie dzieła sztuki nie leży w sferze samego piękna oderwanego od życia bądź bytującego, jako luksusowy dodatek, na jego marginesie. Zahorska domagała się twórczości, która nie będzie odgradzać się od życia złotymi ramami ${ }^{31}$. Z zadowoleniem witała więc hasła utylitaryzmu zrywającego $\mathrm{z}$ romantycznym uwznioślaniem sztuki, traktowaniem jej jako ucieczki do wyższego, idealnego życia. Postulaty konstruktywistów wydawały się potrzebne szczególnie w Polsce, która wciąż, w jej przekonaniu, nie potrafiła wyzwolić się z ,zaczadzającego umysły" ideału sztuki pisanej przez duże „S”, ze szlacheckiej obawy przed rzemiosłem, a co za tym idzie, z przeświadczenia, że „sztuka zaczyna się tam, gdzie się kończy wytwarzanie dla praktycznych celów" ${ }^{\prime 2}$. Zahorska $\mathrm{z}$ aprobatą przyjmowała kierunek, w którym rozwijała się warszawska Szkoła Sztuk Pięknych w większym stopniu nastawiona na rozwój rzemiosł artystycznych. Nie bez racji zauważyła jednak, że postulat wkraczania sztuki w życie ma u nas wciąż wydźwięk typowo burżuazyjny - miarą utylitaryzmu jest bowiem salon mieszczański, a artyści, jeśli lepią garnki, to nie na wodę, lecz do ustawienia ich na etażerce $^{33}$. Większe szanse widziała więc $\mathrm{w}$ konstruktywizmie, ale i wobec tego nurtu nie pozostawała bezkrytyczna.

Konstruktywizm traktowała Zahorska jako boczne „koryto” kubizmu, a jednocześnie jego dopełnienie, dostosowanie do praktycznego, nowoczesnego życia, choć z wyrugowaniem jakiejkolwiek metafizyki czy poszukiwań przedmiotu jako bytu niezmiennego ${ }^{34}$. Doceniała śmiałe nowatorstwo, celowość, odrzucenie tradycji oraz poszukiwanie nowych materiałów i środków technicznych. Utylitaryzm postrzegała jednak jako zjawisko cenne szczególnie z perspektywy sztuk

\footnotetext{
${ }^{29}$ Eadem, Symbolika form, s. 2.

${ }^{30}$ Eadem, Pro i contra, s. 4.

${ }^{31}$ Eadem, Sztuka wolnej Polski, ,Słowo Polskie” 1928, nr 313, s. 9.

${ }^{32}$ Eadem, Zdobić czy tworzyć, „Wiek XX” 1928, nr 16, s. 1.

${ }^{33}$ Ibidem.

${ }^{34}$ Stefania Zahorska, Kubizm i jego pochodne, „Południe” 1924, nr 1, s. 42-51.
} 
użytkowych. Jej zastrzeżenia budziło natomiast konsekwentne stosowanie tej miary w sztukach plastycznych: bezwzględnie zracjonalizowany stosunek do przedmiotu, jednostronność oraz popadanie w niewolę zasad produkcji czyni z formy - pisała - przymusowy wynik raczej niż samoistne zagadnienie, a tym samym przeczy autonomicznej woli artystycznej, proponując $\mathrm{w}$ zamian formalny determinizm. Mimo swych lewicowych poglądów Zahorska nie była w stanie zaakceptować antyindywidualistycznej wizji sztuki. Niepokoił ją również nadmiernie intelektualny charakter konstruktywizmu. Co ciekawe, oceniając dokonania plastyków tego nurtu stosowała retorykę nieodbiegającą znacząco od skrajnie negatywnych recepcji konstruktywizmu obecnych w ówczesnej prasie, zwłaszcza konserwatywnej, w której mnożyły się wówczas zarzuty o brak artyzmu, pomijanie człowieka, bezduszność, rozumowość, a prace artystów sprowadzane były do rangi bądź eksperymentów geometry, bądź dziecięcej zabawki ${ }^{35}$. Zahorska naturalnie nie usuwała skrajnej awangardy poza nawias sztuki, ale i w jej tekstach pojawiały się tak znamienne określenia odnoszące się do prac konstruktywistów, jak „krwawa operacja na duszy”, „klasztorna srogość jednostronności” czy „,bezindywidualny bezradosny chłód”36. Sztuka tworzona bez udziału podświadomości, oczyszczona z wszelkich „bakterii emocjonalnych” i tworzona „w antyseptycznej atmosferze świadomości i rozumu” wydawała się jej wizją zgoła przerażającą - niczym „gorset, pod którym nie ma

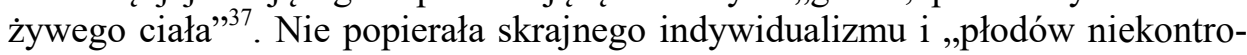
lowanej rozumem wyobraźni”, jednak sprowadzanie pracy artysty do roli inżyniera w kolektywie było w jej przekonaniu równie szkodliwą krańcowością. Podobnie jak redukowanie sztuki do produkcji czysto intelektualnej, zracjonalizowanej, ignorującej nie tylko metafizykę, ale też podświadomość, irracjonalizm, fantazję czy jakiekolwiek emocjonalne napięcie. Domagając się od sztuki emocjonalnej obudowy i ładunku uczuciowego Zahorska nigdy nie stanęła w szeregu krytyków tradycjonalistycznych, zażarcie walczących z przeintelektualizowaniem awangardy $\mathrm{w}$ imię nowej, humanistycznej treści dzieła. Monografistka Zaka nigdy też nie włączyła się w debatę o sztuce narodowej ${ }^{38}$, roli tematu czy o społecznych powinnościach artysty. Były to spory, które zdominowały dyskurs krytyczny w latach trzydziestych, kiedy uwaga Zahorskiej skupiła się przede wszystkim na filmie i reportażu. Być może nie bez pewnego wpływu na kształtowanie się jej poglądów miały nastroje, jakie panowały już

\footnotetext{
${ }^{35}$ Zob. Piotr Piotrowski, Awangarda między estetyka a polityka. Konstruktywizm polski w opinii publicznej, 1921-1934, w: Władysław Strzemiński, 1893-1952. Materiały z Sesji, red. Jadwiga Janik, Muzeum Sztuki, Łódź 1994, s. 108-124.

${ }^{36}$ Ibidem.

${ }^{37}$ Ibidem.

${ }^{38}$ Jedyny znany mi przykład, to głos krytyczki w sprawie sztuki żydowskiej. Podkreśla tam wyraźnie, iż wszelkie próby świadomego i celowego tworzenia sztuki narodowej muszą ,spalić na panewce” - zwłaszcza takie, w których „narodowość” wyraża się wyłącznie w temacie i zapleczu ideowym - „narzucona sobie wewnętrzna tendencja odrębności stanowi poważną przeszkodę w zdobyciu artystycznego poziomu, kierując artystów na fałszywą drogę tematycznego romantyzmu”. Zob. Stefania Zahorska, Sztuka żydowska, „Wiek XX” 1928, nr 12, s. 5.
} 
pod koniec lat dwudziestych w całej Europie, gdzie wołania o „powrót do porządku" i neohumanizm coraz częściej wyprzedzały dotychczasowe tendencje formalistyczne. Poczucie powszechnego kryzysu, stagnacji, upadku wartości moralnych, odczuwane pod wpływem wydarzeń I wojny światowej, nasilało się w kolejnych latach, znajdując kulminację w popielcowych nastrojach wywołanych krachem na amerykańskiej giełdzie w 1929 roku i jego bolesnych reperkusjach odczuwanych również w całej Europie. Zahorska nigdy jednak nie uległa tej kryzysowej retoryce. Co więcej, widząc u progu lat trzydziestych, także wśród dawnych awangardzistów, rezygnację z poszukiwań formalnych na rzecz powrotu do klasycyzmu czy nowego realizmu ${ }^{39}$, ostrzegała przed pochopnym wieszczeniem końca awangardy. Ponadto przekonywała, że nawet gdy sztuka ta przejdzie do lamusa, jej historyczna wartość pozostanie niepodważalna. Występowała $\mathrm{w}$ ten sposób przeciwko modnym wówczas próbom „chirurgicznego usuwania” tego, czego nie udało się zrozumieć, oburzając się na wszelkie zabiegi deprecjonowania awangardy, uznawania jej za dziecięce igraszki niegodne powagi czasów ${ }^{40}$. Wydaje się zatem, iż jej niebezkrytyczny stosunek do skrajnego modernizmu nie tyle był efektem ówczesnych tendencji artystycznych, ile raczej rezultatem jej artystycznego światopoglądu, ściśle określonej koncepcji sztuki stanowiącej swoisty konglomerat myślenia postromantycznego $\mathrm{z}$ myśleniem formalistycznym ${ }^{41}$. Zahorska oczekiwała nadejścia nowej sztuki, która nie miała jednak rozwijać się w kontrze do awangardy, lecz powstać z przeniknięcia się stanowiska ekspresjonistów i kubokonstruktywistów, tj. na styku mistycznych tęsknot i maszynowych ideałów. Sztuki, która, nie wstydząc się uczucia, a jednocześnie nie wyrzekając się rozumu, nie będzie ani mamić hasłami matematycznych ścisłości, ani też szukać kamienia filozoficznego w kanonach i formułach ${ }^{42}$. A zatem, choć rozumiała pobudki konstruktywistów i doskonale zdawała sobie sprawę z ich drogi rozwojowej czy programu, uważała, że ów nurt mógł być jedynie stadium przejściowym, rodzajem półpiętra, na którym zatrzymała się sztuka, by wejść na kolejną kondygnację. Monografistka Matejki nie miała bowiem wątpliwości, że „na podłożu psychicznym wyłącznie rozumowej kalkulacji” nie może powstać twórczość wielka ${ }^{43}$. Odrzucając sztukę pisaną przez duże „S”, sztukę „zaczadzającą umysły Polaków" "44 Zahorska, jak się wydaje, też uległa - przynajmniej częściowo - owemu zaczadzeniu. Relikty takiego romantycznego myślenia, traktującego sztukę jako wieczny, nieuchwytny i przemawiający do duszy byt, są jeszcze bardziej wyraźne w jej recenzjach i sprawozdaniach z wystaw.

\footnotetext{
${ }^{39}$ Zob. Stefania Zahorska, Wystawa Berlewiego, „Wiadomości Literackie” 1928, nr 3, s. 3.

${ }^{40}$ Eadem, Pro i kontra, s. 4.

${ }^{41}$ Myślenie to bliskie było choćby szkole lwowskiej, reprezentowanej przez Jana Bołoza-Antoniewicza i Kazimierza Twardowskiego.

${ }^{42}$ Stefania Zahorska, Przegląd usiłowań, „Sztuki Piękne” 1925, nr 12, s. 568-571.

${ }^{43}$ Eadem, Kubizm i jego pochodne, s. 51.

${ }^{44}$ Eadem, Zdobić czy tworzyć, s. 1.
} 
NIEUPRZEDZONYM OKIEM. HORYZONT ODBIORCZY I KRYTERIA OCENY DZIEŁ SZTUKI

Stojąc na stanowisku pluralizmu oraz historycznego relatywizmu uznającego tymczasowość wszelkich kryteriów i uwzględniającego przede wszystkim założenia oraz „wolę artystyczną” danego czasu, Zahorska nie widziała przeszkód, by pozytywnie pisać zarówno o impresjonizmie, jak i kierunkach, które narodziły się w efekcie zanegowania impresjonistycznych założeń. Odcinała się tym samym od tych spośród ówczesnych krytyków, dla których „,uznanie zasług impresjonizmu czy klasycyzmu pokrywa się na ogół z odpowiednio groźnym wystąpieniem przeciwko modernizmowi. Jeśli impresjonizm jest coś wart, to oczywiście, sztuka abstrakcyjna musi być eo ipso »nonsensem«, szaleństwem, bolszewizmem itd." ${ }^{45}$ Ale drażniło ją również potępianie w czambuł impresjonizmu, który w krytyce polskiej, zwłaszcza w pierwszych latach międzywojnia, figurował jako klasyczny „chłopiec do bicia”, antonim formy i negatywny punkt odniesienia dla młodej sztuki. Zdaniem Zahorskiej ta powierzchowna i niesprawiedliwa ocena była efektem stosowania fałszywej miary, podobnej do tej, jaką twórcy renesansu stosowali wobec dokonań wielu mistrzów średniowiecznych - a więc miary pragnień obcych założeniom omawianego nurtu. Surowo oceniając swoich kolegów po piórze Zahorska po raz kolejny sytuuje się ponad nimi - i dotyczy to nie tylko obrońców dawnego porządku, ale też orędowników nowej sztuki. Krytyka antyimpresjonistyczna dowodziła, jej zdaniem, paradoksalnej niemożności wyrwania się ze zmysłowego stosunku do świata. Tymczasem wyrazisty, jednak daleki mimo wszystko od jednostronności światopogląd pozwalał krytyczce pozytywnie - choć bez gorliwości neofitki - pisać o programie skrajnej awangardy, zaakceptować sztukę umiarkowanego, centrowego (wedle jej nomenklatury) Rytmu, ale też doceniać zarówno formalne eksperymenty impresjonistów, jak również dokonania Jana Matejki czy Henryka Rodakowskiego. Odporna była tylko na poczynania skrajnej artystycznej prawicy, zwłaszcza dyletanckich i anachronicznych obrazów wystawianych wówczas masowo w warszawskiej Zachęcie uznawanej przez nią i wielu innych ówczesnych publicystów za „rozsadnik najtęższego nieuctwa i najbanalniejszego wstecznictwa" ${ }^{46}$.

Horyzont oczekiwań Zahorskiej jako odbiorczyni sztuki był mimo wszystko wyraźnie określony, a kryterium zdecydowanie dominującym w jej systemie aksjologicznym pozostawało niezmiennie nowatorstwo, z którym w parze szło sprawdzanie szans rozwojowych i potencjału analizowanych nurtów czy dzieł sztuki. Powstawanie kierunków artystycznych ma w jej przekonaniu rację bytu

\footnotetext{
${ }^{45}$ Eadem, Pro i contra, s. 4.

${ }^{46}$ Eadem, Wystawa „Rzeźba polska” i obrazy Zrzeszenia Polskich Artystów Plastyków w Zachęcie, „Wiadomości Literackie” 1927, nr 21, s. 4.
} 
tylko wówczas, gdy są one „wykładnikami rozwojowych konieczności zbiorowej psychiki" 47 , wyzwalają nowe siły, realizują nowe możliwości bytu i poszukują nowych rozwiązań formalnych. Zahorska ceniła więc impresjonizm, który doprowadził do powstania największych zmian w sztukach plastycznych, nadał kierunek twórczości artystycznej na dziesięciolecia, i o którego sile świadczy choćby fakt, że wciąż nie został do końca zwalczony. Ale ceniła również ekspresjonizm - za postawienie nowego zagadnienia, obranie nowej, antyimpresjonistycznej drogi odrzucającej supremację rozumowo-zmysłowego poznania na rzecz irracjonalnych pierwiastków duszy. Wreszcie, także ostateczny bilans awangardy mimo wszystkich zastrzeżeń wypadał w jej ujęciu pozytywnie. Zahorska wykazywała jednostronność i wszelkie niedociągnięcia tej sztuki, doceniła jednak wartość samego dążenia do stworzenia nowych i lepszych ram życia (konstruktywizm) oraz nowej gramatyki form (kubizm). Nie zadowalały ją ostatecznie osiągnięte rezultaty, widziała jednak cenne zdobycze mogące stać się podstawą dla sztuki przyszłości. Przede wszystkim jednak awangarda, tak jak wcześniej impresjonizm, ekspresjonizm i dawne wielkie formacje, zrodziła się z ducha nowoczesności, była więc odpowiedzią na powstanie nowego człowieka.

W Polsce zasługi pionierstwa i stworzenia podstaw dla nowej sztuki dostrzegała Zahorska głównie w twórczości formistów, wyróżniając zwłaszcza Witkacego - za odwagę walki i traktowanie sztuki w kategoriach czynu, choćby sprowadzonego głównie do negacji i niekonsekwentnie przeprowadzonego w praktyce artystycznej. Tymczasem nasza skrajna konstruktywistyczna awangarda spotkała się już z mniejszym uznaniem krytyczki, która miast nowatorstwa widziała tu raczej bierność, lękliwość i przyzwoity burżuazyjny spokój. W zachodniej sztuce przerażała ją krańcowość formalizmu i hipertrofia postulatów utylitaryzmu, na rodzimym podwórku dostrzegała raczej mgławicowość koncepcji, letniość, brak rozmachu i odwagi samotnych poczynań: „Bodajbyśmy sto razy więcej błądzili, [...] ale niechby w tym wszystkim było gorętsze tętno, niechby walka o nowe była walką o życie - a nie tym ostrożnym stawianiem nóg po schodach z poręczą"

Odważne poszukiwanie nowych dróg i wytyczanie szlaków dla rozwoju sztuki przyszłości wydawało się dla Zahorskiej wartością znacznie istotniejszą niż znaczenie już osiągniętych rezultatów. Starała się więc wyczuć to, co jest „zdobywczym nastawieniem się na nowe wartości, co jest poszukiwaniem nowego materiału estetycznych przeżyć” i co „może nawet nieurzeczywistnione, kryje w sobie potencję przyszłości” " Nowość i nowatorstwo to w jej słowniku krytycznym niemal synonimy twórczości jako takiej. Kompilacyjne żerowanie

\footnotetext{
${ }^{47}$ Eadem, Filozofia ekspresjonizmu, s. 66.

${ }^{48}$ Eadem, Przegląd usitowań, s. 571.

${ }^{49}$ Eadem, Pro i contra, s. 4.
} 
na przeszłości, karmienie się „odpadkami z pańskich stołów”, choćby to były stoły zastawione suto sztuką nowoczesną, uznawała za dowód upadku i braku życia sztuki. Taką muzealną martwotą były w jej mniemaniu przede wszystkim prace członków Bractwa św. Łukasza oraz klasyków wileńskich - reprezentujące najnowszą, „rozsądną” generację artystów pozbawionych odwagi eksperymentowania ${ }^{50}$. Brak niespodzianek, konieczności rewizji i nowych rozkoszy wzrokowych zauważała również na kolejnych wystawach Rytmu ${ }^{51}$. Nudą i sztampą były dla niej wreszcie dokonania nestorów krakowskiej Sztuki, w których widziała jedynie rekapitulację i dalszą eksploatację wcześniejszych (nienegowanych przez nią) osiągnięć, powtarzanie tych samych zasad w rozmaitych konfiguracjach, brak ciągłości rozwoju i odwagi kroczenia pod innymi sztandarami $^{52}$. Zdecydowanie wyżej ceniła natomiast koloryzm - idący co prawda zgodnie z linią rozwojową zainicjowaną przez (post)impresjonizm, ale wyciągający zeń konstruktywne wnioski.

Nowatorstwo w języku krytycznym Zahorskiej jest kryterium mierzonym przede wszystkim za pomocą rozwiązań formalnych. I jest to zjawisko wówczas powszechne, można by nawet rzec, konstytutywne dla ówczesnej, zwłaszcza postępowej, krytyki międzywojennej, w której forma staje się orężem w walce

\footnotetext{
${ }^{50}$ Zahorska nie podzielała powszechnych wówczas zachwytów nad malarstwem Bractwa, uznając jego przedstawicieli za obiecujących, jednak wciąż zbyt szkolnych i „niegotowych”. Najwyżej oceniła obrazy Bolesława Cybisa, widząc w nich rys indywidualny, subtelną kolorystykę oraz równowagę „między ekspresją a środkami artystycznymi”. W pracach Antoniego Michalaka doceniła „napięcie ekspresyjne”, zarzucając jednak malarzowi zbyt mało nowoczesną „paseistyczną syntezę”, „hałas barwny” i powierzchowność formy. Jej surowa krytyka prac Jana Gotarda wynikała z „kardynalnego braku barwy”, prace pozostałych malarzy uznała zaś za powierzchowne, zbyt łatwe, niekiedy „bezdusznie dosłowne”, ale nade wszystko odtwórcze. Konkludując, doceniła jednak poszukiwania kolorystyczne, wszczepione przez założyciela bractwa prof. Tadeusza Pruszkowskiego, wyrażając nadzieję, że w przyszłości szkoła stanie się chlubą malarstwa polskiego. Zob. Stefania Zahorska, Bractwo św. Lukasza, „Wiadomości Literackie” 1928, nr 12 , s. 3 .

51 Według Zahorskiej Rytm reprezentował skręt na prawo części buntowników rewolucji formalistycznej w Polsce: sztukę „,spokojną i miękką w formie”, „dekoracyjną w kompozycji, przesyconą reminiscencjami klasycznej przeszłości i motywami polskimi”, dbającą o piękną linię i kompozycję. Zob. Stefania Zahorska, Sztuka wolnej Polski, „Słowo Polskie” 1928, nr 313, s 9. Recenzując VIII wystawę Rytmu w 1927 roku krytyczka uznała wartości grupy za czysto „muzealne”, niedające żadnych ,nowych rozkoszy wzrokowych”. Zdecydowanie wyróżniła jedynie dokonania Wacława Wąsowicza głównie z uwagi na czysto malarskie właściwości jego sztuki: bezpośrednie wyczucie materii i „zmysłową rozkosz farby”. Stefania Zahorska, Wystawa Rytmu i Wacława Wąsowicza, „Wiadomości Literackie” 1927, nr 27, s. 3.

${ }^{52}$ Recenzując wystawę „Sztuki” w 1924 roku Zahorska krytycznie odniosła się zwłaszcza do dokonań młodszej generacji artystów, dowodząc, iż nie wykazuje ona „żadnej tendencji szukania nowych dróg, żadnych prób ku samodzielności lub choćby przewartościowania. W miłym półśnie maluje dziś tak jak przed laty dwudziestu i szuka rozwiązania tych samych zagadnień, co wówczas. Nic nowego - żadnego świeżego tchnienia". Zob. Stefania Zahorska, Wystawy obrazów w Krakowie, „Południe” 1924, nr 1, s. 70.
} 
o zmianę wartości estetycznych i nawyków odbiorczych, synonimem artyzmu i prawdy, jedynym sprawdzianem jakości dzieła, narzędziem walki z impresjonizmem i młodopolskimi duszostanami. Jednocześnie jednak owa forma, jako swego rodzaju wytrych otwierający drzwi nowoczesnej sztuki, zdaje się być wówczas terminem samotłumaczącym się, niewymagającym dodatkowych uściśleń. A jeśli definiowanym, to w sposób mało precyzyjny, daleki od konsekwencji i uzgodnionych stanowisk ${ }^{53}$. Zahorska tymczasem nie tylko nie uciekała przed podaniem ścisłej definicji, ale obudowywała ją dodatkowymi wyjaśnieniami. Forma była dla niej „odpowiednikiem spojrzenia na rzeczywistość od strony kształtu”. Rodzajem transpozycji, „pewnym systemem interpretującym, rekonstrukcją, którą obowiązuje konsekwencja wobec obranego raz punktu wyjścia, i która zatraca swój sens właściwy, jeśli (...) staje się tylko recytowaniem mniej lub więcej dosłownym kształtów rzeczywistych" ${ }^{54}$. Choć sam bieg linii, jak pisała krytyczka, nie daje jeszcze formy, niezbędnym warunkiem jej zaistnienia jest zamknięcie płaszczyzny lub bryły - budowanie formy jest zatem tworzeniem wyodrębnionych, zamkniętych w sobie całości (płaskich lub iluzorycznych). Tak rozumiana forma wydaje się leżeć na antypodach zagadnień związanych z barwą. I faktycznie, na ogół Zahorska te dwa podstawowe składniki obrazu wyraźnie rozdzielała (pisząc np. za Wölfflinem o malarskości i linearności czy za Rieglem o wzrokowości lub haptyczności sztuki). Dopuszczała jednak możliwość - jak to widziała choćby u Paula Cézanne’a - budowania formy poprzez kolor. Jednak nawet barwa pozbawiona funkcji formotwórczej nie wyklucza, jej zdaniem, istnienia malarskiej kompozycji. Komponowaniem nazywała ona bowiem nie tylko wiązanie różnorodnych jednostek formalnych w zamkniętą i zwartą masę, ale też tworzenie (budowanie) obrazu według jakiejkolwiek prawidłowości w układzie. Pozwalało jej to uznać za skomponowane - choć jednostronnie, bo wyłącznie przy pomocy równoważących się plam barwnych - także płótna impresjonistyczne.

W słowniku krytycznym Zahorskiej forma i kompozycja to pojęcia kluczowe, odmieniane przez wszystkie przypadki i wzbogacane najrozmaitszymi określnikami. Zahorska jednak formy nie absolutyzuje - uznaje zarówno prace, w których jest ona celem nadrzędnym, jak i środkiem podporządkowanym treści, służącym zmaterializowaniu artystycznej wizji (ekspresjonizm). Ideałem dla krytyczki było takie dzieło, w którym forma jawi się jako wartość sama w sobie, czynnik niezbędny, „wewnętrznie konieczny” i jednocześnie organicznie związany z treścią (a więc będący - choćby pośrednio - wyrazem jakiejś idei, wizji, rzeczywistości duchowej czy jakiegokolwiek stosunku twórcy do świata).

Atrybutami formy funkcjonującymi w jej recenzjach jako składniki oceny pozytywnej są: zwartość, jednolitość, rzetelność, syntetyczność, określoność,

\footnotetext{
${ }^{53}$ Zob. Diana Wasilewska, Przełom czy kontynuacja, s. 89-109.

${ }^{54}$ Stefania Zahorska, Kronika. Sztuki plastyczne, „Przegląd Warszawski” 1924, nr 40, s. 81.
} 
konsolidacja czy prawidłowość. Jeśli natomiast w omawianych obrazach dominuje widzenie przedmiotowe, mowa jest o formie słabej, gąbczastej, miękkiej, amebowatej, nieokiełznanej, nieuchwytnej - takiej więc, która w gruncie rzeczy jest aformą, a więc surogatem czy zaprzeczeniem formy.

Tropiąc zgodność teoretycznych założeń z praktyką artystyczną, Zahorska szczególnie surowo odnosiła się do jakości formalnych dzieł cenionego przez nią skądinąd Witkacego. Widziała w nich jaskrawy przykład niezrealizowanego postulatu, miast czystej formy dostrzegała bowiem nieokiełznane „wylewanie treści na płaszczyznę” i supremację barwy, która „buja” po nieukształtowanych masach $^{55}$. Barwa jako taka, choćby nawet wyabstrahowana od formy, jednak będąca świadomym założeniem artysty, nie jest jednak przez Zahorską bagatelizowana czy negowana. Przeciwnie - z zadowoleniem przyjmowała ona choćby tendencje kolorystyczne w polskim malarstwie końca lat dwudziestych i w kolejnej dekadzie. Doceniała zwłaszcza ekspresyjne napięcie barwy - szczególnie, jeśli uwolniona od światła i przedmiotu oddziałuje ona jako bezpośredni środek wyrazu treści emocjonalnych. Dynamizm krzyku Zahorska przeciwstawiała jednak ,jarmarcznej krzykliwości” i „kolorystycznemu nożownictwu”, jakie dostrzegała choćby na obrazach Fryderyka Pautscha, gdzie siła i żywotność barw nie podlegają tak ważnemu dla niej kompozycyjnemu planowi obrazu, podporządkowując się nadmiernie przedmiotowi ${ }^{56}$. Czasem jednak Zahorska dawała się ponieść ekspresyjnym, nastrojowym, a zwłaszcza zmysłowym walorom barwy. Dzieje się tak choćby przy omawianiu prac Zofii Stryjeńskiej, która oczarowała ją swym malarskim temperamentem, bezpośrednim stosunkiem do życia i niesłychanym urokiem, który „porywa widza, zabija w nim wszelką dążność do analizy i intelektualizowania, czyni go uległym od pierwszego wrażenia i każe mu się tylko cieszyć tem, że istnieje taki prosty i tak bezpośrednio z formą związany pozytywny stosunek do życia" ${ }^{57}$. Zmysłowy, a nawet synestetyczny wymiar koloru podziwiała Zahorska w obrazach Tymona Niesiołowskiego, które „dyszą zapachem [...] olejnej farby" ${ }^{\text {" }}$ czy Tadeusza Pruszkowskiego, który „w końcach palców ma wyczucie farby i pędzla” i dzięki temu „tworzy barwne symfonie, gdzie nawet czerń nabiera dziwnej miąższości, połyskliwej głębi i faluje" 59 . Zahorska pisała nadto o kolorach „,zjadliwych” lub „surowych”, ale też o „wełnistych”, stalowych czy mięsistych strukturach, rozpływała się nad rozkoszą „tłustej, ciężkiej i błyszczącej” barwy oraz podziwiała gęste i zmysłowe wyczucie materii.

\footnotetext{
${ }^{55}$ Eadem, Kronika. Sztuki plastyczne, „Przegląd Warszawski” 1924, nr 35, s. 375.

${ }_{57}^{56}$ Eadem, O los polskiego impresjonizmu, s. 270.

${ }^{57}$ Eadem, Kronika. Sztuki plastyczne, „Przegląd Warszawski” 1924, nr 30, s. 396.

${ }^{58}$ Eadem, Wystawa Wileńskiego Towarzystwa Plastyków w Zachęcie, „Wiek XX” 1928, nr 2, s. 45.

${ }^{59}$ Eadem, Wystawa Pruszkowskiego, „Wiadomości Literackie” 1927, nr 51, s. 3.
} 
W swoich recenzjach z wystaw krytyczka rzadko decydowała się na opisy i analizy poszczególnych prac. Przeważają wypowiedzi uogólniające, choć niekoniecznie aksjologicznie neutralne, próbujące za pomocą kilku zdań określić zasadniczy rys twórczości danego plastyka. W tych nielicznych przypadkach Zahorska nie była jednak konsekwentna. Potrafiła $\mathrm{z}$ jednej strony dokonać drobiazgowego rozbioru formalnego obrazu - czego przykładem jest choćby analiza jednej z kubistycznych martwych natur Henryka Stażewskiego ${ }^{60}-\mathrm{z}$ drugiej zaś dawała się ponieść nastrojowi i wyrazowej sile dzieła. Dzieje się tak choćby w tekście poświęconym wystawie Henryka Gotliba w Instytucie Propagandy Sztuki (IPS) w 1938 roku. Zahorska omawia tu wiele kwestii, w tym pozorną tylko - w jej mniemaniu - zależność malarza od sztuki impresjonistycznej. Gdy jednak dochodzi do opisów - które płynnie przenikają się z analizą i interpretacją - wizjonerski, ekspresyjny charakter obrazów w zasadniczy sposób określa też styl i tonacje krytycznej wypowiedzi: „Ciemnawe purpury - pisała, omawiając obraz Rodzina - stanowią tło jakby pełne zadumy [...]. Twarze - ledwo muśnięte pędzlem, a jest w nich całe przeżyte życie, choć nic się nie dzieje, choć siedzą tylko nieruchomo, tych dwoje, którzy zmierzają do kresu i ten, który życie zaczyna - rodzina, ojciec, matka i syn, odwieczna niezmienna trójca ludzka" "61. W tym opisie, którego nie powstydziłby się zapewne niejeden z krytyków młodopolskich, odsłania się pękniecie dające się zauważyć także - a może nawet w większym stopniu - w minimonografiach. Tu bowiem język krytyczny Zahorskiej - tak precyzyjny, pojęciowy, trzymany w ścisłych ryzach władz intelektu w artykułach syntetycznych, polemicznych czy postulatywnych - ulega znacznemu rozluźnieniu, zbaczając niekiedy nawet w stronę tak krytykowanej przez nią egzaltacji i pretensjonalności.

Krytyczka nie rezygnowała co prawda $\mathrm{z}$ analiz formalnych, nie stanowiły one jednak celu jej pracy badawczej. Jak pisała w książeczce o Matejce, przez analizę form próbowała dojść do duszy artysty ${ }^{62}$. Była to w pewnym sensie konsekwencja jej poglądu mówiącego, że twórca, budując obrazy, wypowiada jednocześnie jakąś wizję świata. Metoda przeprowadzona tu przez Zahorską znacząco jednak ciąży w stronę psychologizmu, wskazując na żywotność ekspresyjnych teorii artystycznych o postromantycznym, młodopolskim rodowodzie, a tym samym dowodząc pilnie odrobionej lekcji z Crocego i Lippsa raczej niż z Worringera i formalistów. Widać to jeszcze wyraźniej w monografii o Zaku. Jej autorka nie tylko wyjaśniła tematyczne wybory malarza (ucieczkę w marzenie i bajkę traktując jako sublimację poczucia dysharmonii w życiu realnym), nie tylko wskazała na bezpośrednie przełożenie psychicznych predys-

\footnotetext{
${ }^{60}$ Eadem, Kubizm i jego pochodne, s. 36-37.

${ }^{61}$ Eadem, Malarstwo Henryka Gotliba, „Wiadomości Literackie” 1938, nr 21, s. 10.

${ }^{62}$ Eadem, Matejko, Wydawnictwo Gebethner i Wolff, Warszawa 1925, s 13.
} 
pozycji i stanów twórcy na dominujący nastrój obrazu, ale nawet czysto plastyczne jakości kompozycji, takie jak linia, rytm czy barwa, omawiała przez pryzmat osobowości artysty. Pisała więc o Zaku, iż ów „lubuje się w linii”, „szczerze” korzysta ze zdobyczy tradycji, kieruje nim ,pragnienie dekoracyjności”, a jego konstrukcja psychiczna „o charakterze miękkim i subtelnym nie pozwalała mu wkroczyć na drogę formalnego, przebojowego nowatorstwa" ${ }^{63}$. Ukazując przeobrażenia, jakim ulegała sztuka malarza, Zahorska nie opisywała dzieł jako gotowych artefaktów - za iście romantyczną nierozdzielnością artysty i jego wytworu przemawiają tu choćby zwroty w stylu: „szuka dróg do dekoracji”, „ma potrzebę tradycji”, ,jego konstrukcja psychiczna nie pozwalała mu...". Pisanie o dziełach poprzez analizę stanów emocjonalnych i charakteru twórcy, szukanie w jego temperamencie wyjaśnienia ewolucji stylowych czy konkretnych rozwiązań formalnych - tego rodzaju krytyka, kojarzona przede wszystkim z impresjami młodopolskimi, w okresie międzywojennym nie stanowiła wcale reliktu funkcjonującego już tylko na obrzeżach profesjonalnej krytyki. Przeciwnie nawet. Młodopolski ekspresywizm pokutował zarówno w prasie codziennej i u nestorów krytyki wychowanych na romantyczno-naturalistycznym światopoglądzie, jak też wśród orędowników krytyki naukowej (Mieczysław Treter, Mieczysław Wallis), a wreszcie w środowisku propagatorów metody formalistycznej i zwolenników tzw. nowej sztuki. Jego echa znajdziemy np. w tekstach Tadeusza Peipera analizującego twórczość Fernanda Légera czy w Witkacowych próbach odczytania obrazów Rafała Malczewskiego $^{64}$. Nie ustrzegła się przed nim także Zahorska, choć, oddając sprawiedliwość tej krytyczce przyznać trzeba, iż zarówno ekspresyjny styl odbioru, jak też afektywny, nadmiernie emocjonalny ton wypowiedzi nie były w jej dorobku dominujące. Ich obecność świadczy jednak o tym, iż wyzwolenie się z pewnych kalek językowych, zużytych kryteriów i wypartych, jak się wydawało, narzędzi interpretacyjnych było dużo trudniejsze, niż to zakładała Zahorska, tworząc swój program nowoczesnej, tj. wolnej od balastu przeszłości, krytyki artystycznej.

${ }^{63}$ Eadem, Eugeniusz Zak, Wydawnictwo Gebethner i Wolff, Warszawa 1927, s. 5-6.

${ }^{64}$ Zob. Marjan Bielski [Tadeusz Peiper], Fernand Léger, ,Zwrotnica” 1922, nr 1, s. 12; Stanisław Ignacy Witkiewicz, Wystawa Rafata Malczewskiego w Zakopanem, w: O znaczeniu..., s. 172-179 (pierwodruk: „Epoka” 1927, numery 222, 228, 235). 


\section{BIBLIOGRAFIA}

Głowala Wojciech, Młodopolska wyobraźnia metakrytyczna, Wydawnictwo Uniwersytetu Wrocławskiego, Wrocław 1985.

Karcz Danuta, Stefanii Zahorskiej walka o treść, „Kwartalnik Filmowy” 1960, nr 1-2, s. 47-92.

Nasiłowska Anna, Stefania Zahorska $i$ wiek XX [wstęp], w: Stefania Zahorska, Wybór pism. Reportaże, publicystyka, eseje, red. Anna Nasiłowska, Instytut Badań Literackich PAN, Warszawa 2010, s. 5-52.

Pilch Anna, Symbolika form i kolorów. O krytyce artystycznej Stefanii Zahorskiej, wyd. Księgarnia Akademicka, Kraków 2004.

Piotrowski Piotr, Awangarda między estetyka a polityką. Konstruktywizm polski $w$ opinii publicznej 1921-1934, w: Władystaw Strzemiński, 1893-1952. Materiaty z Sesji, red. Jadwiga Janik, Muzeum Sztuki, Łódź 1994, s. 108-125.

Rudziński Piotr, Między konformizmem a awangarda. O krytyce Stefanii Zahorskiej, w: Sztuka dwudziestolecia międzywojennego. Materiaty Sesji SHS, PWN, Warszawa 1982, s. 93-103.

Strzemiński Władysław, Stefania Zahorska: „Impresjonizm a najnowsze malarstwo francuskie” [recenzja], „Zwrotnica” 1926, nr 7, s. 205.

Wasilewska Diana, Mieczysław Treter - estetyk i krytyk sztuki oraz "szara eminencja” międzywojennego życia artystycznego w Polsce, Towarzystwo Autorów i Wydawców Prac Naukowych Universitas, Kraków 2019.

Wasilewska Diana, Przetom czy kontynuacja. Polska krytyka artystyczna 1917-1930 wobec tradycji młodopolskiej, Towarzystwo Autorów i Wydawców Prac Naukowych Universitas, Kraków 2013.

Wasilewska Diana, Stefania Zahorska - pierwsza reporterka II Rzeczpospolitej, w: Kobiece dwudziestolecie 1918-1939, red. Radosław Sioma, Wydawnictwo Naukowe Uniwersytetu Mikołaja Kopernika, Toruń 2018, s. 227-241.

Witkiewicz Stanisław Ignacy, Bez kompromisu, red. Janusz Degler, Państwowy Instytut Wydawniczy, Warszawa 1976.

Witkiewicz Stanisław Ignacy, O znaczeniu filozofii dla krytyki i inne artykuly polemiczne, oprac. Jan Leszczyński, PWN, Warszawa 1976.

Zahorska Stefania, Bractwo św. Łukasza, „Wiadomości Literackie” 1928, nr 12, s. 3.

Zahorska Stefania, Eugeniusz Zak, Wydawnictwo Gebethner i Wolff, Warszawa 1927.

Zahorska Stefania, Filozofia ekspresjonizmu. (Uwagi na tle malarstwa), „Przegląd Warszawski” 1924 , nr 28, s. 48-66.

Zahorska Stefania, Kronika. Sztuki plastyczne, „Przegląd Warszawski” 1924, nr 30, s. 392-397.

Zahorska Stefania, Kronika. Sztuki plastyczne, „Przegląd Warszawski” 1924, nr 40, s. 79-84.

Zahorska Stefania, Kronika. Sztuki plastyczne, „Przegląd Warszawski” 1925, nr 45, s. 372-378.

Zahorska Stefania, Krytyka wobec modernizmu, „Praesens” 1926, nr 1, s. 41-42.

Zahorska Stefania, Kubizm i jego pochodne, „Południe” 1924, nr 1, s. 31-51.

Zahorska Stefania, Malarstwo Henryka Gotliba, „Wiadomości Literackie” 1938, nr 21, s. 10.

Zahorska Stefania, Malarstwo Picassa, „Wiadomości” 1950, nr 51/52 (247/248), s. 2.

Zahorska Stefania, Matejko, Wydawnictwo Gebethner i Wolff, Warszawa 1925.

Zahorska Stefania, Niematerialistyczne teorie sztuki, „Wiadomości” 1958, nr 641, s. 2.

Zahorska Stefania, O los polskiego impresjonizmu, „Sztuki Piękne” 1926/27, nr 7, s. 258-270.

Zahorska Stefania, Pro i contra, „Wiek XX” 1928, nr 1, s. 4.

Zahorska Stefania, Przegląd usiłowań, „Sztuki Piękne” 1925, nr 12, s. 568-571.

Zahorska Stefania, Symbolika form, „Wiadomości” 1949, nr 42 (185), s. 2.

Zahorska Stefania, Szkice o literaturze i sztuce, red. Paweł Kądziela, Wydawnictwo Książkowe Twój Styl, Warszawa 1995. 
Zahorska Stefania, Sztuka wolnej Polski, „Słowo Polskie” 1928, nr 313, s. 9.

Zahorska Stefania, Sztuka żydowska, „Wiek XX” 1928, nr 12, s. 4-5.

Zahorska Stefania, Treść czy abstrakcja, „Wiek XX” 1928, nr 13, s. 4.

Zahorska Stefania, Wystawa „Rzeźba polska” i obrazy Zrzeszenia Polskich Artystów Plastyków w Zachęcie, „Wiadomości Literackie” 1927, nr 21, s. 4.

Zahorska Stefania, Wystawa Pruszkowskiego, „Wiadomości Literackie” 1927, nr 51, s. 3.

Zahorska Stefania, Wystawa Rytmu i Wactawa Wasowicza, „Wiadomości Literackie” 1927, nr 27, s. 3.

Zahorska Stefania, Wystawa Wileńskiego Towarzystwa Plastyków w Zachęcie, „Wiek XX” 1928, nr 2, s. 45.

Zahorska Stefania, Wystawy obrazów w Krakowie, „Południe” 1924, nr 1, s. 70-71.

Zahorska Stefania, Zdobić czy tworzyć, „Wiek XX” 1928, nr 16, s. 1.

\section{IN SEARCH OF MODERN CRITICAL LANGUAGE AVANT-GARDE ART IN THE APPROACH OF STEFANIA ZAHORSKA}

This text is an attempt to examine Zahorska's art criticism, primarily her statements about the avant-garde. The author analyses Zahorska's evolving views and her concept of art, considering her aesthetic and methodological inspirations, as well as the criteria by which she evaluated works of art and artistic movements. Making a crushing assessment of the state of interwar art criticism, Zahorska repeatedly called for the rejection of impressionist pattern and the creation of a new model of writing capable of facing modern art. Her own practice was also to be the answer to these needs. For this reason, special attention is given in the article to the language of Zahorska' art criticism - the concepts developed by the critic, the rhetoric of expression, the mode of reception dominant in her texts, etc. This makes it possible to present the specificity of her writing and determine the place of Zahorska in the field of interwar art criticism in Poland.

\section{Keywords}

Stefania Zahorska, interwar period, art criticism, avant-garde, form 